\title{
An Overview of Medical Students' Psychological in The Process of Distance Learning on Pandemic COVID-19
}

\author{
Gladys D T Tubarad*, Mirsyam Ratri Wiratmoko, Silmi Nur Aulia, Seline Calysta \\ Prameswari, Satya Pramana
}

Medical Study Program, Faculty of Medicine and Health, Universitas Muhammadiyah Jakarta, Indonesia

*Corresponding author: gladys_tubarad@yahoo.com

\begin{abstract}
Background: The spread of COVID-19 in Indonesia in June 2020 does not yet show signs of a decrease. Therefore, Indonesia's Ministry of Education and Culture takes preventive transmission in the educational environment by making the decision letter with four ministers agreeing that learning in higher education of the academic year 2020/2021 in all zones shall be held online. Online learning is a learning system that does not need face to face directly but uses a platform that can help the process of distance learning. The burden of learning materials and academic demands of medical students can cause students anxiety, especially in the pandemic COVID-19. Purposes: to determine an overview of the medical students' psychological in distance learning during the pandemic COVID-19. Methods: This is a crosssectional study using descriptive quantitative analysis. The data used primary data through Depression Anxiety and Stress Scale (DASS-21) questionnaire. Results: The results of the study showed that the highest percentage is at mild anxiety about $47.3 \%$, mild stress level with $7.8 \%$, and mild depression that $13.2 \%$. Factors that can lead to psychological disorders in medical students, the demands of learning, and a sense of worry excessive about the process and the results. Conclusions: Factors that lead to anxiety, stress, and depression in medical students when implementing distance learning can be different for each individual.
\end{abstract}

Keywords: anxiety stress, depression, distance learning, medical student

\section{INTRODUCTION}

Coronavirus Disease 2019 (COVID-19) is an infectious disease caused by Severe Acute Respiratory Syndrome Coronavirus 2 (SARS-CoV-2). SARS-CoV-2 is a new type of coronavirus that has never been previously identified in humans. Common signs and symptoms experienced in patients with COVID-19, among others, are acute respiratory distress such as fever, cough, and shortness of breath. The average incubation period is 5-6 days for the incubation of the longest 14 days. In the case of COVID-19 are severe, it can cause pneumonia, acute respiratory syndrome, kidney failure, and even death (1,2).

Spread of COVID-19 that have an impact on the increasing number of victims, extensive coverage of the affected region, as well as the implications on the socioeconomic aspects in Indonesia, then issued Presidential Decree No. 12 of the Year 2020 on the Determination of the Disaster Non Nature the Spread of COVID-19 as a 
National Disaster (1).

After the Indonesian government declared that the COVID-19 was a national disaster, some local governments closed schools and universities for a while. All of the learning processes are held online as of Monday, March 16, 2020 (3). In line with local government regulations, the Faculty of Medicine and Health (FMH) of the University of Muhammadiyah Jakarta (UMJ) is also conducting distance learning to prevent the spread of COVID-19 $(4,5)$.

The spread of COVID-19 in Indonesia in June 2020 has yet to show signs of decline, on the contrary, still increasing. Therefore, the Ministry of Education and Culture took steps to prevent the transmission of the educational environment by making the Decision Letter Along with 4 Ministers agreed that the process of learning, especially in higher education in the odd semester of the academic year 2020/2021, in all zones shall be held online for the course theory. At the same time, practice courses are also done online (4).

As mentioned in the Regulation of the Minister of Education and Culture Republic of Indonesia No. 109 of 2003, distance education is the teaching and learning process done remotely through various communication media. Distance learning also can make the students have a breadth of time in learning (6).

The uncertainty of educators, the confusion of parents who accompany their children to study at home, problems with infrastructure, connection problems, and students' confusion about online learning methods accompanied by piles of tasks have caused widespread anxiety, especially during the COVID-19 pandemic. Prolonged and continuous anxiety can cause stress that interferes with daily activities and can cause depression for students. The responsibilities and demands of academic life on students can be part of the stress experienced by students (7). Therefore, researchers are interested in knowing the psychological of students who do distance learning.

\section{METHODS}

The research is quantitative research with a descriptive approach method, using the cross-sectional approach. This research was conducted in FMH UMJ Cirendeu and Cempaka Putih during NovemberDecember 2020 using primary data obtained through a questionnaire containing the questions compiled on the DASS-21.

DASS is a questionnaire used to determine the level of depression, anxiety, and stress in a person. This questionnaire is not a diagnostic tool but can be used as a tool to assess the severity of the stress conditions. DASS has also been translated into several languages and used widely in the scope of the study or the daily practice. The questionnaire is easily applied to a population and does not require special training in its application. DASS-21 is a short version of the DASS-42. DASS-21 has twenty-one statements which consist of seven statements to assess the level of anxiety, stress, and depression a person (8). This data was obtained directly from the results of research through a questionnaire with a Likert scale to find out the psychological of students of the FMH UMJ medical study program in the distance learning process during the COVID-19 pandemic.

The sample in this study were students of the FMH UMJ medical study program who were still active. The sampling technique used was the total 
sampling method, and all respondents were medical students of FMH UMJ who were still involved in distance learning.

The received data will be carried out an inspection of the truth, editing, decoding, tabulated, and entered into the computer data analysis includes the analysis of test data descriptive. In the descriptive analysis, the value of the continuous scale will be expressed as the average and standard deviation.

This research has received ethical approval from the Health Research Ethics Commission, Faculty of Medicine and Health, University of Muhammadiyah Jakarta number 2015/PE/KE/FKK-UMJ/ XII/2020.

\section{RESULT}

This study involved 205 respondents who are still active in the 2017-2020 FMH UMJ Medical Study Program for the 2020-2021 academic year. Characteristics of respondents are presented in Table 1.

Table 1. Characteristics of the study respondents $(\mathrm{N}=205)$

\begin{tabular}{ccc}
\hline Characteristics & $\begin{array}{c}\text { Frequency } \\
\text { (n) }\end{array}$ & $\begin{array}{c}\text { Percentage } \\
(\%)\end{array}$ \\
\hline Gender & 49 & 23.9 \\
Male & & 76.1 \\
Female & 156 & \\
Years of Students & & 26.3 \\
2017 & 54 & 10.7 \\
2018 & 22 & 20 \\
2019 & 41 & 43 \\
2020 & 88 & \\
\hline
\end{tabular}

The results of this study, the total female respondents amounted to $76.1 \%$, more than the male respondents amounted to $23.9 \%$. Based on the research obtained, the proportion of respondents in the study in Year of Students of 2017 was as much as $26.3 \%$, the $201810.7 \%$, class of 2019 as much as $20 \%$, and the class of 2020 as much as $43 \%$.

\section{Distribution of Respondents Based on the Level of Anxiety, Stress and Depression Respondents}

On the level of anxiety (Figure 1), respondents who have mild anxiety is $47.3 \%$ and the normal is $52.7 \%$. The distribution of the stress level on the respondents, mainly in the category of normal, which is experiencing mild stress by $7.8 \%$ and moderate stress is by $2.4 \%$. The distribution of depression level of the respondents, majority of the respondents in the category of normal, but $13.2 \%$ of respondents in the category of mild depression, $7.8 \%$ in the category of moderate depression, and $0.5 \%$ in the category of severe depression.

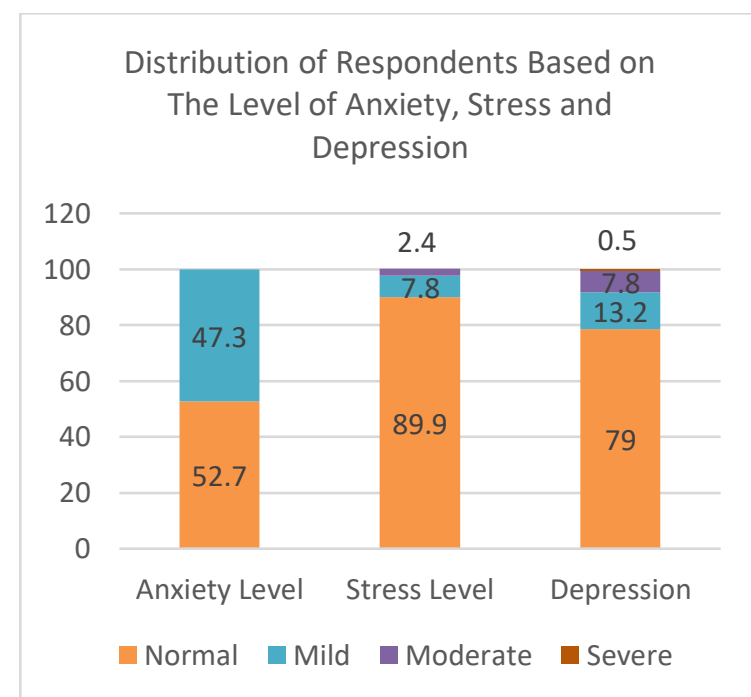

Figure 1. Distribution of Respondents Based on the Level of Anxiety, Stress and Depression Respondents (in Percent)

The Level of Anxiety, Stress and Depression by Gender

By gender, the percentage of the level of anxiety, stress and depression in female is higher than male on all levels, both normal, mild, moderate, or severe (figure 2). 
The Level of Anxiety, Stress and

Depression Based on Gender

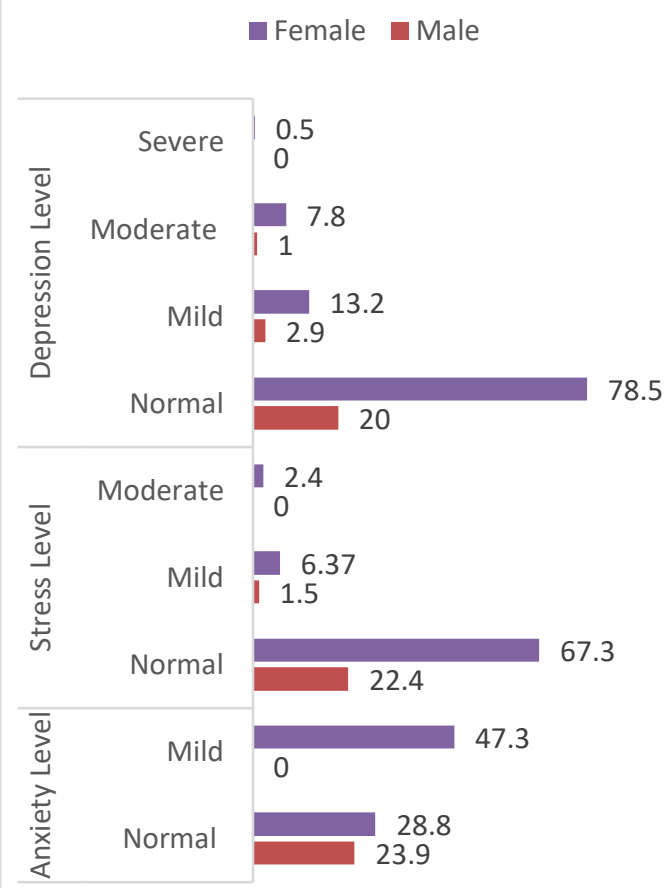

Figure 2. Levels of Anxiety, Stress and Depression of Respondents by Gender (in Percent)

Table 2. Distribution of Anxiety Disorders Based on Year of Students

\begin{tabular}{cccrr}
\hline \multirow{2}{*}{$\begin{array}{l}\text { Year of } \\
\text { Students }\end{array}$} & \multicolumn{4}{c}{$\begin{array}{c}\text { Distribution of Anxiety } \\
\text { Disorders }\end{array}$} \\
\cline { 2 - 5 } & \multicolumn{2}{c}{ Normal } & \multicolumn{2}{c}{ Mild } \\
\cline { 2 - 5 } & n & \multicolumn{1}{c}{ \% } & \multicolumn{1}{c}{ \% } \\
\hline 2017 & 27 & 13.2 & 27 & 13.2 \\
2018 & 16 & 7.8 & 6 & 2.9 \\
2019 & 26 & 12.7 & 15 & 7.3 \\
2020 & 39 & 19 & 49 & 23.9 \\
Total & 108 & 52.7 & 97 & 47.3 \\
\hline
\end{tabular}

The research results in Table 2 showed that the proportion of respondents with the highest level of anxiety is a mild level in year 2020. On stress disorder, either mild or moderate, with the highest percentage of year 2020 amounting to $3.4 \%$ and $2 \%$ (Table 3). Based on Table 4, showed the percentage of respondents with depressive disorders mild and moderate the highest is on the 2020 rate of $5.9 \%$ and $4.4 \%$. While severe depressive disorders the highest is in 2017 by $0.5 \%$.

Table 3. The Distribution of Stress Disorders Based on Year of Students

\begin{tabular}{ccccccc}
\hline \multirow{2}{*}{$\begin{array}{c}\text { Year of } \\
\text { Students }\end{array}$} & \multicolumn{3}{c}{ The Distribution of Stress Disorders } \\
\cline { 2 - 7 } & \multicolumn{2}{c}{ Normal } & \multicolumn{2}{c}{ Mild } & \multicolumn{3}{c}{ Moderate } \\
\cline { 2 - 7 } & $\mathbf{n}$ & $\mathbf{\%}$ & $\mathbf{n}$ & $\mathbf{\%}$ & $\mathbf{n}$ & $\mathbf{\%}$ \\
\hline 2017 & 48 & 23.4 & 5 & 2.4 & 1 & 0.5 \\
2018 & 22 & 10.7 & 0 & 0 & 0 & 0 \\
2019 & 37 & 18 & 4 & 2 & 0 & 0 \\
2020 & 77 & 37.6 & 7 & 3.4 & 4 & 2 \\
Total & 184 & 89.8 & 16 & 7.8 & 5 & 2.4 \\
\hline
\end{tabular}

Table 4. The Distribution of Depressive Disorders Based on Year of Students

\begin{tabular}{ccccccccc} 
Year of & \multicolumn{3}{c}{ The Distribution of Depressive Disorders } \\
\cline { 2 - 9 } Students & \multicolumn{2}{c}{ Normal } & \multicolumn{3}{c}{ Mild } & Moderate & Severe \\
\cline { 2 - 8 } & $\mathbf{n}$ & $\%$ & $\mathbf{n}$ & $\%$ & $\mathbf{n}$ & $\%$ & $\mathbf{n}$ & $\%$ \\
2017 & 43 & 21 & 8 & 3.9 & 2 & 1 & 1 & 0.5 \\
2018 & 16 & 7.8 & 4 & 2 & 2 & 1 & 0 & 0 \\
2019 & 35 & 17.1 & 3 & 1.5 & 3 & 1.5 & 0 & 0 \\
2020 & 67 & 32.7 & 12 & 5.9 & 9 & 4.4 & 0 & 0 \\
Total & 161 & 78.5 & 27 & 13.2 & 16 & 7.8 & 1 & 0.5 \\
\hline
\end{tabular}

\section{DISCUSSION}

\section{The Anxiety Level of Respondents}

Table 2 shows an overview of the level of anxiety experienced by the medical students FMH UMJ who are still active in academic learning activities, of which $47.3 \%$ had mild anxiety and $52.7 \%$ normal.

The anxiety experienced by students can be caused by several factors ranging from the academic level, the demands of learning, a new environment that encourages students to adapt. Anxiety experienced by students in distance learning, namely the emergence of a sense of worry against network interruptions when students follow distance learning activities, especially when going to the holding of the exam. Students who are required to understand the test material must also be enveloped in the sense of worry about the ongoing process of the exam online. The level of anxiety in students the initial level has a level of 
anxiety that the mild anxiety as much as 49 students $(23.9 \%)$, while in the final year students have higher levels of anxiety the number two highest mild anxiety as much as 27 students (13.2\%). The same case with the research conducted by Achmad Fariz Ramadhan (2019) on the students of the Faculty of Medicine, University of Lampung that the level of anxiety in students the initial level has a higher amount with an average of 14.1 while on the final level students with an average of 9.53. Causes of anxiety in students of the early levels can occur because of the tight schedule of lectures and lab work on the first-year curriculum of the college, the lack of time with family, and refreshing with friends. While in the final level of the student final project/thesis, the preparation of the Objective Structured Clinical Examination (OSCE) comprehensive final exam before the Education Profession (Co Assistant) in the hospital (9).

This research is consistent with research that has been done by M. Luthfi Mandani (2017) in the Medical Education Study Program of UMJ The female respondents were more anxious than male respondents. Female respondents experienced mild anxiety $(9.82 \%)$ and moderate anxiety $(0.89 \%)$, while the male respondents $(3.57 \%)$. Many women experience anxiety because men are more active in the day and exploratory, while women have a more sensitive side (9).

\section{The Stress Level of Respondents}

Based on Table 3 shows an overview of the level of stress experienced by medical students of FMH UMJ who are still active in the academic learning activities, $2.4 \%$ of college students experienced moderate stress, $7.8 \%$ of students had mild stress, and
$89.8 \%$ of students did not experience stress/normal.

Based on the research, the author did that the level of stress on students' beginning level is higher than the student's final level, namely the category of mild stress as much as seven students (3.4\%) and stress are as many as four students (2\%). In comparison, the final year students had mild stress as much as five students $(2.4 \%)$ and mild stress of being as much as one student $(0.5 \%)$.

Factors that can cause a state of stress on students at the end of them because it felt like a failure in self-adjustment, college expenses are piling up, economic factors, a relationship friend/spouse, a career in the future, and the lack of time management. While at the level of the student's initial experience of stress can occur due to a change adaptation time from school to the university, where to stay far away from parents and the environment that are less good (10).

Based on the research results, the level of stress on the female respondents is more than the male respondents. The female respondents with mild stress as much as 13 students $(6.3 \%)$ and stress are a total of 5 students $(2.4 \%)$, whereas in male respondents with mild stress as many as three students $(1.5 \%)$.

On women's stress level more than men, the same is the case with the research conducted by Rizkia Dwina Rahmayani (2017) on First-Year Medical Students at the University of Andalas Padang. The stress response is different in men and women associated with the sympathetic nervous system, which will give a negative response when the body is subjected to stress and the activity of the HPA axis (11). HPA axis and the sympathetic nervous sys- 
tem, which will give the feedback, are negative when the body is experiencing stress. HPA axis regulates the production of the hormone cortisol, whereas the sympathetic nervous system works in the setting of heart rate and blood pressure. The response of the HPA and autonomic higher in men affects a person's response to the stressor. In addition, sex hormones in women will lose the response of the HPA and sympathoadrenal, which can cause a decrease in a feedback negative hormone cortisol to the brain so that women tend to be easy to stress (12).

Several things influence stress experienced by the students due to the outbreak of COVID-19. Some of the things that become stressors for students when the outbreak of COVID-19 is ongoing, namely the fear of contracting COVID-19, the concern is when you go out of the house, the boredom while doing social distancing, and difficulty understanding the material during lectures online (13). Another study found that management training stress on students is very effective. Students can understand the material on stress management delivered and practice independently (14). This is because stress can be positive or negative depending on the perception of the person who feels it. If the ability to deal with stress is not good enough, and the demands are very high, the stress will increase (15). Management training stress in medical students is essential to make the students more skilled in coping with stress in the era of online learning so that it can achieve the desired results (14). Some ways to reduce stress include, among others, consuming healthy and nutritious foods, maintaining physical fitness, doing breathing exercises, doing fun activities, taking a vacation, avoiding bad habits, planning daily routines, keeping plants and animals, sparing time for oneself or families, and avoiding loneliness. A stress-reducing program can be successful if it is seriously carried out with discipline (16).

\section{The Depression Level of Respondents}

Table 4 shows an overview of the depression level experienced by students that following the activities of the academic learning, it is still found in the category of severe, moderate, and mild depression even though the rates are a little.

Many medical students have depression which can be caused by several factors, like gender, where women are two times more prone to depression due to hormonal factors, socio-economic factors, and culture like the new environment, new friends, and money to lectures, as well as the learning curriculum of medicine where medical students are required to be always self-learning outside of the course (17).

Alkhowailed 2020 finds that contrary to the results of this study, students feel satisfied at the session of the learning problem-based learning (PBL) with the online method in the era of Covid-19. Students do not feel stressed or depressed because the online method makes learning sessions PBL more effective (18). Although the cognitive aspects can be done online, the other psychomotor and affective aspects are difficult to implement with the online method because of the need for direct contact between the teacher and the students to transfer this competence (19). Another study found that online learning makes students more successful in achieving the learning goal compared to students who learn in a face-to-face. However, students with learning styles audio and visual score higher on the online learning system, the students with 
kinesthetic learning styles are also not found a gap value that far (20).

\section{CONCLUSION}

Based on the study results, an overview of medical students psychological in the process of distance learning on pandemic COVID-19, it can be concluded that percentage is the highest in the category of mild anxiety, mild stress, and mild depression. Female respondents tend to have the highest proportion of anxiety, stress, and depression at all levels compared with men. When implementing distance learning, factors that lead to medical students experiencing stress, anxiety, and depression can differ for each individual.

\section{ACKNOWLEDGMENT}

Thank you to the Faculty of Medicine and Health, University of Muhammadiyah Jakarta, and the various parties who have provided input and support during the study.

\section{CONFLICT OF INTEREST}

None.

\section{REFERENCES}

1. Kementerian Kesehatan Republik Indonesia. Pedoman Pencegahan dan Pengendalian Corona Virus deases (Covid-19) [Internet]. Vol. 5, Kementerian Kesehatan. 2020. p. 178. Available from: https://covid19 .go.id/storage/app/media/Protokol/R EV-05_Pedoman_P2_COVID-19_1 3_Juli_20 20.pdf

2. Tim Kerja Kementerian Dalam Negeri. Pedoman Umum Menghadapi Pandemi Covid-19 Bagi Pemerintah Daerah: Pencegahan, Pengendalian, Diagnosis dan Manajemen. 2013 p. 1689-99.
3. BBC News Indonesia. Virus corona: Sekolah, universitas meniadakan kelas, pemerintah Indonesia belum resmi liburkan sekolah [Internet]. 2020 [cited 2020 Nov 10]. Available from: https://www.bbc.com/indonesia/indonesia-517 69074

4. Direktorat Jenderal Pendidikan Tinggi Kemdikbud Republik Indonesia. Buku Panduan Penyelenggaraan Pembelajaran Semester Gasal 2020/2021 di Perguruan Tinggi. Jakarta: Direktorat Jenderal Pendidikan Tinggi Kemdikbud Republik Indonesia; 2020. p. 29.

5. Pratiwi EW. Dampak Covid-19 Terhadap Kegiatan Pembelajaran Online Di Sebuah Perguruan Tinggi Kristen Di Indonesia Salatiga: Perspektif. Universitas Kristen Satya Wacana. Perspekt Ilmu Pendidik. 2020;34(1):1-8.

6. Menteri Pendidikan dan Kebudayaan. Peraturan Menteri Pendidikan dan Kebudayaan No 1092013 Tentang Penyelenggaraan Pendidikan Jarak Jauh Pada Pendidikan Tinggi. Jakarta; 2013.

7. Hasanah U, Ludiana L, Immawati I, PH L. Psychological Description of Students in the Learning Process During Pandemic Covid-19. J Keperawatan Jiwa [Internet]. 2020 Jul 14;8(3):299. Available from: https://jurnal.unimus.ac.id/index.ph $\mathrm{p} / \mathrm{JKJ} /$ article/view/5941

8. Indira IE. Stress Questionaire: Stress Investigation From Dermatolgist Perpective. In: Psychoneuroimmu nology in dermatology. Bali: PERDOSKI dan Bag SMF Ilmu Kesehatan Kulit dan Kelamin FK UNUD; 2016. p. 135-52.

9. Ramadhan AF, Sukohar A, Saftarina 
F. Perbedaan Derajat Kecemasan Antara Mahasiswa Tahap Akademik Tingkat Awal dengan Tingkat Akhir di Fakultas Kedokteran Universitas Lampung. Medula [Internet]. 2019;9(1):78-82. Available from: https://juke.kedokteran.unila.ac.id/i ndex.php/medula/article/view/2355

10. Agusmar AY, Vani AT, Wahyuni S. Perbandingan Tingkat Stres pada Mahasiswa Angkatan 2018 dengan Angkatan 2015 Fakultas Kedokteran Universitas Baiturrahmah. Heal Med J. 2019;1(2):34-8.

11. Rahmayani RD, Liza RG, Syah NA. Gambaran Tingkat Stres Berdasarkan Stressor pada Mahasiswa Kedokteran Tahun Pertama Program Studi Profesi Dokter Fakultas Kedokteran Universitas Andalas Angkatan 2017. J Kesehat Andalas [Internet]. 2019 Mar 31;8(1):103. Available from: http:// jurnal.fk. unand.ac.id/index.php/jka/article/vie w/977

12. Wang J, Korczykowski M, Rao H, Fan Y, Pluta J, Gur RC, et al. Gender difference in neural response to psychological stress. Soc Cogn Affect Neurosci. 2007 Sep 1;2(3):227-39.

13. Sari MK. Tingkat stres mahasiswa s1 keperawatan tingkat satu dalam menghadapi wabah covid 19 dan perkuliahan daring di stikes karya husada kediri. J Ilm Pamenang. 2020;2(1):31-5.

14. Ureka Hakim GR, Tantiani FF, Shanti P. Efektifitas Pelatihan Manajemen Stres Pada Mahasiswa. J Sains Psikol [Internet]. 2017 Nov 7;6(2):76-80. Available from: http://journal2.um.ac.id/index.php/J SPsi/article/view/1641
15. Lumban Gaol NT. Teori Stres: Stimulus, Respons, dan Transaksional. Bul Psikol. 2016;24(1):1.

16. Sukadiyanto S. Stress dan Cara Menguranginya. J Cakrawala Pendidik [Internet]. 2010 May 24;1(1). Available from: https://journal. uny.ac.id/index.php/cp/article/view/ 218

17. Hardjosoesanto AJ, Sarjana AS W, Jusup I. Hubungan Antara Tingkat Depresi Dengan Tingkat Sugestibilitas Pada Mahasiswa Fakultas Kedokteran Tahun Pertama. J Kedokt Diponegoro [Internet]. 2017 ;6(2):288-96. Available from: https: //ejournal3.undip.ac.id/index.php/m edico/article/view/18544

18. Alkhowailed MS, Rasheed Z, Shariq A, Elzainy A, El Sadik A, Alkhamiss $A$, et al. Digitalization plan in medical education during COVID19 lockdown. Informatics Med Unlocked [Internet]. 2020;20:100 432. Available from: https://linking hub.elsevier.com/retrieve/pii/S2352 914820305827

19. Rozaliyani A, Widjaja HT, Prawiroharjo P, Sukarya W. Kajian Etik Pendidikan Jarak Jauh dalam Pendidikan Kedokteran di Indonesia. J Etika Kedokt Indones. 2020;4(2) $: 57$.

20. Anggrawan A. Analisis Deskriptif Hasil Belajar Pembelajaran Tatap Muka dan Pembelajaran Online Menurut Gaya Belajar Mahasiswa. MATRIK J Manajemen, Tek Inform dan Rekayasa Komput [Internet]. 2019 May 30;18(2):339-46. Available from: https://journal.universitasbumigora.ac.id/index.php/matri k/article/view/411 